\title{
Factors Influencing Farmers' Adaptations to Climate Variability and Extreme Events in Dry Kitui, Kenya
}

\author{
Kamau M.W*, Ndung'u C.K and Muriu Ng'ang'a F.W \\ Department of Environment, Land and Natural Resource Management, South Eastern Kenya University, Kenya
}

Submission: March 04, 2020; Published: March 17, 2020

*Corresponding author: Mercy Wanjiku Kamau, Department of Environment, Land and Natural Resource Management, South Eastern Kenya University, P.O. BOX 170 - 90200, Kitui County, Kenya

\section{Abstract}

There is an increasing recognition of the role of climate change adaptation among farmers who depend on rain-fed agriculture in Africa. However, due to a range of factors, many farmers particularly in the rural areas have barely adopted sufficient adaptation measures and have continued to suffer losses from the inherent effects of climate variability and extremes. A study based on farming households' survey was conducted in selected sub-locations in Kitui County to gain insights on the adaptation strategies used by farmers against climate variability and extreme events and factors influencing their adoption. Purposive and cluster sampling methods were applied in identifying the sub-locations of study while proportionate and systematic sampling were used to select the households which formed the units of analysis. A total of 341 households from Yuku, Kaveta, Kauwi and Kasaini sub-locations, located in arid, semi-humid, transition from semi- arid to semi-humid and semi-arid zones respectively constituted the study's sample size. The results indicated that there was a statistically significant relationship between agro-ecological zones and adoption of building water-harvesting schemes, planting trees for shade, irrigation, use of chemical fertilizer, use of organic manure, improved crop variety, agro-forestry, integrated pest management, moving herd from one place to another, migration to urban areas and use of pesticides $(\mathrm{p}<0.1)$. Further, results of the Logistic regression analysis showed that gender, education level, farming experience and age significantly $(\mathrm{p}<0.05)$ ) influenced adoption of adaptation strategies to climate variability and extremes in the study areas. The study identified the need for intense agricultural extension training and climate change sensitization among farmers to ensure that feasible adaptations are promoted and factors influencing adoption of adaptation strategies addressed.

Keywords: Climate variability; Adaptation strategies; Logistic regression

\section{Introduction}

Climate change and variability is expected to adversely affect agriculture in sub-Saharan Africa (SSA) particularly the Arid and Semi-Arid Lands (ASALs). It has been projected that climate variability and extremes will reduce agricultural production by $10-20 \%$ by 2050 [1]. The projected reduction will mainly result from the changing rainfall patterns and the increase in the frequency of extreme weather events. This will also increase the prevalence of crop pests and diseases [2]. The effects of these changes are expected to be severe in SSA, where persistent poverty and massive dependence on agriculture makes populations in this region more vulnerable than in other parts of the world. Given this vulnerability, it is necessary to identify and embrace suitable adaptation strategies to climate variability and extremes among rural farming communities in Kenya. Most of agricultural adaptations to climate variability and extremes involves ecological, social and economic systems adjustments as a reaction to actual or expected climatic stimuli,their effects or impacts $[3,4]$. The success of adaptation measures by farmers is determined by the adaptive capacity of the farmers which greatly influence vulnerability of households, communities, groups, sectors, regions, or countries to variations in the climate system [2,5]. Adaptation strategies range from technological, to behavior change at the household and farm level while the types of adaptation range from autonomous, anticipatory to planned adaptations [6]. Studies have reported adaptation strategies in agriculture such as diversification of crops, use of hybrid varieties, use of drought resistant crop varieties, changing of planting dates, water harvesting, irrigation, switching from crop farming to livestock keeping and soil conservation measures [7-9].

Societies have always adapted to natural climate and environmental changes by altering settlement and agricultural patterns and other aspects of their economies and lifestyles throughout the history of man $[10,11]$. Thus, most societies are reasonably adaptable to changes in average conditions, particularly if they are gradual [12]. However, farming households particularly 
in Kitui County are more vulnerable and less adaptable to climate variability and extremes due to low adaptive capacity coupled with biophysical vulnerability. The present study focused on assessment of farmers' adaptation strategies to climate variability and extremes and factors influencing their adoption at household level in dry Kitui, Kenya.

\section{Materials and Methods}

\section{Topography and climate of the study area}

The study area consisted of Yuku, Kaveta, Kauwi and Kasaini sub-locations in Kitui County falling under arid, semi-humid, transitional zone from semi-arid to semi-humid and semi-arid zones respectively. Kitui County is located between longitudes $37^{\circ}{ }^{\circ} 5^{\prime}$ and $39^{\circ} 0^{\prime}$ East and Latitudes $0^{\circ}{ }^{\circ} 3.7^{\prime}$ and $3^{\circ}{ }^{\circ} 0^{\prime}$ South [13]. The county lies between $400 \mathrm{~m}$ to $1,830 \mathrm{~m}$ above sea level and generally slopes from west to east. The climate of the area is semiarid with very erratic and unreliable rainfall. The temperatures range from a minimum of $14-22^{\circ}$ centigrade to a maximum of 26 $34^{\circ}$ centigrade. Rainfall is bimodal distributed within two seasons yearly and varies from $500-1050 \mathrm{~mm}$ with about $40 \%$ reliability. The soil types range from sedimentary rocks, red sandy soils, to clay black cotton soils (Figure 1).

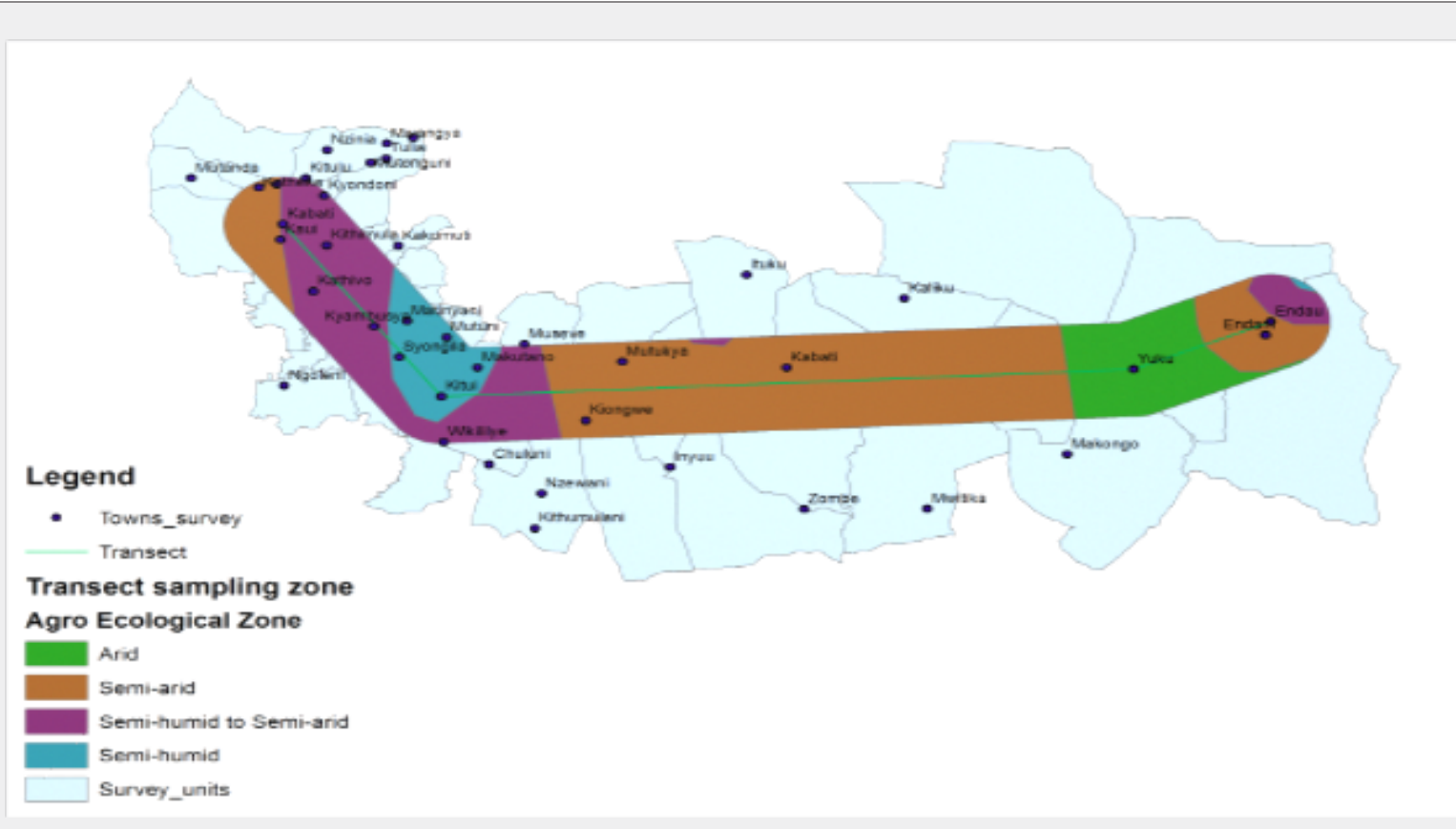

Figure 1: Map of the Study Area.

\section{Population and economy}

Kasaini sub-location had a household population of 2082, Yuku 571, Kaveta 2429 and Kasaini 1911 households. Mixed crop and livestock production are the mainstay of the County, with the balance between the two production systems being determined by the agro-ecological potential. Subsistence production is the main activity. Food crops grown include maize, sorghum, millet, beans, cowpeas, green grams, and pigeon. Cash crops include cotton, sunflower and some coffee (sold as mbuni); green grams are normally grown for commercial purposes.

\section{Research design, data collection and data analysis}

This study used a survey design. Purposive sampling was used to select the sub-locations while systematic random sampling was used to select the households. Households were selected as the main units of analysis because major decisions about adaptation to climate induced stresses and livelihood processes are taken at that level. For this study, Yuku sub-location was selected to represent arid agro-ecological zones, Kaveta semi-humid zones, Kauwi transition zones from semi-arid to semi-humid and Kasaini semi-arid zones of Kitui County. The aim of selecting the four sublocations was to gain insights into differences in perceptions of climate variability and adaptation strategies adopted by farmers in different agro-ecological zones. The sample size for the study was 341 households (Yuku= 39, Kaveta $=104$, Kauwi $=160$ and Kasaini= 38). Primary data was collected through semi-structured interview schedule and personal observation. Statistical Package for Social Sciences (SPSS version 20) was used for data analysis. Descriptive statistics and chi-square tests were run to provide insights into adaptation strategies adopted by farmers in the study areas. Logit regression was performed to assess factors influencing adoption of adaptation strategies by the farmers.

Regression model was applied as outlined by Mutunga et al. [14], albeit in reduced form: 


$$
\begin{array}{r}
Y_{i}=\alpha+\beta_{1} X_{1}+\beta_{2} X_{2}+\beta_{3} X_{3}+\beta_{4} X_{4}+\beta_{5} X_{5}+ \\
\beta_{6} X_{6}+\beta_{7} X_{7}+\beta_{8} X_{8}+\beta_{9} X_{9}+\beta_{10} X_{10} \ldots \ldots \ldots \ldots \ldots \ldots \ldots \ldots \ldots \ldots \ldots \ldots \ldots
\end{array}
$$

Where, $\mathrm{Y}_{\mathrm{i}}$ is a dichotomous dependent variable (adoption or non-adoption of specific adaptation strategies). 0 is the $\mathrm{Y}$ intercept; $\beta_{1}-\beta_{10}$ is a set of coefficients to be estimated; $X_{1}-X_{10}$ are explanatory variables hypothesized by theory and empirical work to influence adoption of adaptation strategies to climate variability and extremes (Table 1).
Equation (1) can be expressed as:

$$
\operatorname{Logit}(p)=\log (p / 1-p)=\alpha+\beta_{1} X_{1}+\beta_{2} X_{2}+\beta_{3} X_{3}+\beta_{4} X_{4}+
$$$$
\beta_{5} X_{5}+\beta_{6} X_{6}+\beta_{7} X_{7}+\beta_{8} X_{8}+\beta_{9} X_{9}+\beta_{10} X_{10}
$$

Where $\mathrm{p}$ is probability that $\mathrm{Y}=1$ i.e. $\mathrm{p}=$ probability $(\mathrm{Y}=1)$.

In term of probability the equation 2 can be expressed as:

$$
P=\frac{\exp \left(\alpha+\beta_{1} X_{1}+\ldots \ldots \ldots \ldots \ldots \beta_{10} X_{10}\right)}{1+\exp \alpha+\beta_{1} X_{1} \ldots \ldots \ldots \ldots \ldots . . . \beta_{10} X_{10}} .
$$

Table 1: Description of explanatory variables that predict probability of farmers' adopting adaptation strategies to climate variability and extremes in the study areas.

\begin{tabular}{|c|c|c|}
\hline Variables & Description of Variables & Hypothesized Influence on Adaptation \\
\hline$X_{1}$ & Age of the household head & $+/-$ \\
\hline$X_{2}$ & Gender of household head & $+/-$ \\
\hline$X_{3}$ & Education level of the household head & + \\
\hline$X_{4}$ & Farming experience & + \\
\hline$X_{5}$ & Off-farm income (annual income from none farm activities) & + \\
\hline$X_{6}$ & Access to credit & + \\
\hline$X_{7}$ & Access to extension services & + \\
\hline$X_{8}$ & Access to climate information and weather forecast & + \\
\hline$X_{9}$ & Agro-ecological zones & $+/-$ \\
\hline$X_{10}$ & & + \\
\hline
\end{tabular}

Note: ${ }^{* * *}$, and ${ }^{*}$ indicate significance at $1 \%$, and $10 \%$ respectively.

Results and Discussion

\section{Adaptation strategies used by farmers in response to climate variability and extremes in the study area}

Results in Table 2 indicated that there was a statistically significant relationship between agro-ecological zones and adoption of building water-harvesting schemes, planting trees for shade, irrigation, use of chemical fertilizer, use of organic manure, improved crop variety, agro-forestry, integrated pest management, moving herd from one place to another, migration to urban areas and use of pesticides $(\mathrm{p}<0.1)$. Adoption of these adaptation strategies was highest in Kaveta and lowest in Yuku. This could be attributed to the intense resource investment needed for installation and maintenance of the strategies. Kaveta was better endowed with financial, human and technological resources compared to the Kauwi, Kasaini Yuku and thus better placed to take up the adaptation strategies that required high resource investment. Moreover, unlike Yuku sub-location, Kaveta sub-location was characterized by intense agriculture which features smart agriculture practices including agro-forestry, integrated pest management, use of chemical fertilizers and use of improved crop varieties. More often, these agricultural practices are also autonomous adaptation strategies to cope with climate variability and extreme events. The results are in agreement with the findings of Mutunga et al. [9] who established a significant difference in the adaptation measures used by farmers in Mikuyuni and Kaveta sub-locations in Kitui County.

Table 2: Adaptation strategies (\%) used by farmers in response to climate variability and extremes.

\begin{tabular}{|c|c|c|c|c|c|c|c|}
\hline Adaptations & Yuku (n=39) \% & $\begin{array}{c}\text { Kaveta } \\
(\mathbf{n = 1 0 4 )} \mathbf{0}\end{array}$ & $\begin{array}{c}\text { Kauwi (n=160) } \\
\mathbf{\%}\end{array}$ & $\begin{array}{c}\text { Kasaini (n=38) } \\
\mathbf{\%}\end{array}$ & $\begin{array}{c}\text { Total (n=341) } \\
\mathbf{\%}\end{array}$ & X2 Value & P-Value \\
\hline $\begin{array}{c}\text { Shift from } \\
\text { livestock } \\
\text { keeping to crops } \\
\text { farming }\end{array}$ & 10.3 & 17.3 & 8.8 & 10.5 & 11.7 & 4.63 \\
\hline $\begin{array}{c}\text { Mixed crop } \\
\text { livestock system }\end{array}$ & 87.2 & 61.5 & 78.1 & 71.1 & 73.3 & 13.2 & 0.2 \\
\hline $\begin{array}{c}\text { Crop } \\
\text { diversification }\end{array}$ & 71.8 & 69.2 & 70 & 68.4 & 69.8 & 0.13 & 0.99 \\
\hline $\begin{array}{c}\text { Plant drought } \\
\text { resilient crops }\end{array}$ & 76.9 & 60.6 & 66.2 & 68.4 & 66 & 3.54 & 0.32 \\
\hline
\end{tabular}


International Journal of Environmental Sciences \& Natural Resources

\begin{tabular}{|c|c|c|c|c|c|c|c|}
\hline $\begin{array}{l}\text { Build a water- } \\
\text { harvesting } \\
\text { scheme }\end{array}$ & 30.8 & 47.1 & 34.4 & 23.7 & 36.7 & 8.6 & $0.04^{* *}$ \\
\hline $\begin{array}{c}\text { Practice reuse } \\
\text { of water }\end{array}$ & 28.2 & 49 & 41.9 & 39.5 & 42.2 & 5.25 & 0.16 \\
\hline $\begin{array}{l}\text { Changing } \\
\text { planting time }\end{array}$ & 82.1 & 73.1 & 72.5 & 71.1 & 73.6 & 1.68 & 0.64 \\
\hline $\begin{array}{c}\text { Soil } \\
\text { conservation } \\
\text { techniques }\end{array}$ & 69.2 & 78.8 & 67.5 & 78.9 & 72.4 & 5.1 & 0.17 \\
\hline Buy insurance & 7.7 & 9.6 & 4.4 & 13.2 & 7.3 & 4.76 & 0.19 \\
\hline $\begin{array}{l}\text { Put trees for } \\
\text { shading }\end{array}$ & 25.6 & 75 & 58.1 & 73.7 & 61.3 & 32.27 & $0.00^{* * *}$ \\
\hline Irrigation & 2.6 & 18.3 & 4.4 & 10.5 & 9.1 & 17.01 & $0.00^{* * *}$ \\
\hline $\begin{array}{l}\text { Reduce the } \\
\text { number of } \\
\text { livestock }\end{array}$ & 53.8 & 39.4 & 35.6 & 34.2 & 38.7 & 4.75 & 0.19 \\
\hline $\begin{array}{l}\text { Increase } \\
\text { livestock } \\
\text { diversity }\end{array}$ & 5.1 & 3.8 & 7.5 & 10.5 & 6.5 & 2.62 & 0.45 \\
\hline $\begin{array}{l}\text { Use animal } \\
\text { feeds } \\
\text { supplements }\end{array}$ & 7.7 & 17.3 & 15 & 10.5 & 14.4 & 2.65 & 0.45 \\
\hline $\begin{array}{l}\text { Migrate to } \\
\text { urban area }\end{array}$ & 10.3 & 2.9 & 1.9 & 5.3 & 3.5 & 6.95 & $0.07^{*}$ \\
\hline $\begin{array}{c}\text { Find off-farm } \\
\text { job }\end{array}$ & 51.3 & 40.4 & 41.9 & 31.6 & 41.3 & 3.14 & 0.37 \\
\hline Lease your land & 2.6 & 6.7 & 1.9 & 0 & 3.2 & 6.34 & $0.09^{*}$ \\
\hline $\begin{array}{l}\text { Use of chemical } \\
\text { fertilizer }\end{array}$ & 2.6 & 55.8 & 8.8 & 50 & 27 & 92.77 & $0.00^{* * *}$ \\
\hline $\begin{array}{l}\text { Use of organic } \\
\text { fertilizer } \\
\text { (manure) }\end{array}$ & 48.7 & 79.8 & 88.8 & 81.6 & 80.6 & 32.27 & $0.00^{* * *}$ \\
\hline $\begin{array}{l}\text { Use minimum } \\
\text { tillage }\end{array}$ & 41 & 48.1 & 35.6 & 28.9 & 39.3 & 6.02 & 0.11 \\
\hline $\begin{array}{l}\text { Use improved } \\
\text { crop varieties }\end{array}$ & 30.8 & 65.4 & 63.8 & 55.3 & 59.5 & 16.34 & $0.00^{* * *}$ \\
\hline $\begin{array}{c}\text { Use of } \\
\text { pesticides }\end{array}$ & 59 & 75 & 69.4 & 84.2 & 71.6 & 7 & $0.07^{*}$ \\
\hline Agro-forestry & 17.9 & 75 & 35.6 & 50 & 47.2 & 54.36 & $0.00^{* * *}$ \\
\hline $\begin{array}{c}\text { Integrated pest } \\
\text { management }\end{array}$ & 28.2 & 55.8 & 43.8 & 39.5 & 45.2 & 9.88 & $0.02^{* *}$ \\
\hline $\begin{array}{l}\text { Seeking support } \\
\text { from veterinary } \\
\text { officers }\end{array}$ & 53.8 & 43.3 & 34.4 & 42.1 & 40.2 & 5.75 & 0.13 \\
\hline $\begin{array}{l}\text { Move herd from } \\
\text { one place to } \\
\text { another }\end{array}$ & 17.9 & 2.9 & 5 & 10.5 & 6.5 & 12.34 & $0.01^{* * *}$ \\
\hline Aquaculture & 0 & 1 & 1.2 & 0 & 0.9 & 0.94 & 0.82 \\
\hline
\end{tabular}

The study revealed that very few respondents had adopted irrigation, aquaculture and buying of insurance. However, adoption of these adaptation strategies was highest in Kaveta sublocation and lowest in Yuku sub-county. This could be attributed to scarcity of water to support irrigation and aquaculture, inadequate financial and technological capacity among the farmers in Yuku sub-location. The high levels of adoption of these strategies in Kaveta sub-location could be explained by the fact that farmers in the area had adequate water to support irrigation and aquaculture. Moreover, Kaveta sub-location was highly endowed with human, financial and technical capacity required to take up these adaptation strategies. 
Further, the results revealed that most households employed multiple adaptation strategies to cope with climate variability and extreme events. For instance most households employed use of organic manure (80.6\%), change of planting time (73.6\%), mixed crop and livestock system (73.3\%), use of pesticides $(71.6 \%)$, crop diversification (69.8\%), planting drought resistant crops (66.0\%), putting trees for shading (61.3\%) and use of improved crop variety at $59.5 \%$. This could be attributed to autonomous adaptations where farmers adopted unplanned adaptations to climate variability and extremes unconsciously. Interestingly, farmers detailed that most of the adaptations were learnt from fellow farmers and not from agricultural extension officers. The current trend of results is in agreement with findings of Fagariba et al. [15] who found that farmers in Sissala West District in Northern Ghana had employed multiple adaptation measures in response to climate variability. This is also in line with findings of Ogallo [16] who found that farmers in Soroti District, Eastern Uganda had employed quite a number of adaptation measures in response to the changing climate and variability.

Crop diversification was identified as an agricultural adaptation to climate variability and extremes in the four sublocations (69.8\%). To a large extent, crop diversification was found to guarantee good harvests. The cultivation of both short and long cycle crop varieties enabled the households to take advantage of the different maturing times of crops, to strengthen their resilience to impacts associated with variable unpredictable rainfalls and drier conditions, in order to increase chances of having good harvest during the drier and wetter seasons. Other farm level adaptation that were common within the four sub-locations included mixed crop-livestock systems, planting drought resilient crops, implementing soil conservation techniques, changing planting time, using organic manure, improved crop variety, use of pesticides and agro-forestry. The result is in agreement with the findings of Paavola [17] who found that farmers altered their mix of crops, switched between crops and changed planting dates as ways of adapting to the evidenced climatic variations. Similarly, findings of Kasirye [18] revealed that farmers in Uganda used mixed cropping and diversification of crops as a form of insurance against rainfall variability and pests attack. The risk of complete harvest failure due to a climatic event such as drought, intense rainfall or high temperature spells, was reduced by having different crops in the same field or various plots with differing crops since not all crops and fields are affected the same way by such climate events [18].

Factors influencing farmers' adaptation to climate variability and extremes in Yuku, Kaveta, Kauwi and

\section{Kasaini sub-locations}

Results of the Logistic regression analysis showed that gender, education level, farming experience and age significantly $(\mathrm{p}<0.05))$ influenced adoption of adaptation strategies to climate variability and extremes in the study areas (Table 3).

Table 3: Odd ratios for factors influencing adoption of adaptation strategies to climate variability and extreme.

\begin{tabular}{|c|c|c|c|c|}
\hline Factors & Coefficient & Wald Statistic & P-value & Odds Ratio \\
\hline Agro-ecological zone & 0.06 & 0.046 & 0.77 & 1.06 \\
\hline Gender & 0.656 & 5.965 & $0.07^{*}$ & 1.93 \\
\hline Access to credit facilities & 0.398 & 2.495 & 0.158 & 1.49 \\
\hline Education level & 0.351 & 0.763 & $0.00^{* * *}$ & 0.96 \\
\hline $\begin{array}{c}\text { Access to extension } \\
\text { services }\end{array}$ & -0.038 & 0.23 & 0.68 & 1.01 \\
\hline $\begin{array}{c}\text { Access to early warning } \\
\text { weather information }\end{array}$ & 0.005 & 0.002 & $0.01^{* * *}$ & 1.02 \\
\hline Farming experience & 0.015 & 2.259 & 0.44 & 1 \\
\hline On- farm income & 0 & 0.985 & 0.77 & 1 \\
\hline Off-farm income & 0 & 1.522 & $0.00^{* * *}$ & 1.02 \\
\hline Age & 0.016 & 2.483 & $0.01^{* * *}$ & 0.26 \\
\hline Constant & -1.357 & 6.094 & \\
\hline
\end{tabular}

The results established that education level of the household head had a significant and positive influence on farmers' adoption of adaptation strategies to climate variability (coefficient $=0.35$, $p=0.00$; odds ratio=1.24). Results indicated that farmers with high education level were more likely to adapt as compared to farmers with low education levels. This could be ascribed to the ability of household heads with high education levels to access and conceptualize information relevant in making innovative decisions. Additionally, households with high levels of education were flexible thus able to take up new adaptation strategies. In similar studies, Gbegeh et al. [19] and Mutunga et al. [14] also established that higher level of education leads to an increase in the adoption of adaptation measure and new technologies.

With reference to age, the current study established that age had a significant and positive influence on adoption of adaptation strategies in the study area (coefficient=1.02; $\mathrm{p}=0.00$; odds ratio=1.02). The odds ratio for age implies that a unit increase in age of the household heads increased the probability of farmers to 
adapt to climate change by a factor of 1.02. This could be attributed to the ability of older farmers to critically assess and weigh adaptation strategies based on their vast farming experience thus making profound decisions on adopting particular strategies. The current trend of results is in consonance with findings of Mutunga et al. [14] who found that older farmers had more experience in farming than younger farmers, hence a higher probability of adopting the adaptation measures. However, the results are contrary to Adesina et al. [20] who found older farmers to be more risk-averse and less likely to be flexible than younger farmers and thus have a lesser likelihood of adopting new technologies.

The farming experience of household heads was also found to have a significant and positive influence of farmers' adoption of adaptation strategies to climate variability and extremes in the study areas (coefficient $=0.01 ; \mathrm{p}=0.01$; odds ratio=1.02). This indicated that farmers with more farming experience were 1.02 times more likely to adopt adaptation strategies compared to those with less farming experience. Farmers who had been in their agricultural holdings for longer year had better knowledge and information on changes in climatic conditions, crop and livestock management practices compared to those who had just started farming. The results are in agreement with findings of Ndungu \& Bhardwaj [8], Deressa et al. [21], and Mutunga et al. [14] who found that increase in farming experience increases the probability of adoption of climate change adaptation measures.

Gender had a positive and statistically significant influence on adoption of adaptation strategies (coefficient $=0.66$; $\mathrm{p}=0.07$; odds ratio=1.93). Households headed by males were 1.93 times more likely to adapt to climate variability and extremes as compared to female-headed households. Interestingly, women in the study areas had more farming experience and information on various management practices and how to change them based on available information, climatic conditions and other factors such as markets and food needs of the households compared to their male counterparts. However, the capacity of women to embrace labourintensive climate adaptations and innovations was undermined as men were the household decision makers and property owners. The results are in consonance with findings of Gbegeh et al. [19] who indicated that in many parts of Africa, women are often deprived of property rights due to social barriers. Consequently, they have fewer capabilities and resources than men (OECD, 2009) [19]. The current result contradicts the findings of Gbetibouo [22] who found that female-headed households were more likely to take up climate change adaptation measures. They reasoned that in most rural smallholder farming communities in Africa, more women than men live in rural areas where much of the agricultural work is done.

Further scrutiny of the results revealed that, agro-ecological zone, access to credit facilities, access to extension services and access to early warning weather information, did not have a statistically significant influence on adoption of adaptation strategies to climate variability and extremes. Nevertheless, the study established that farmers with access to credit facilities were 1.49 times more likely to adopt adaptation strategies compared to those that did not have access to credit (Table 3). Lack of access to credit facilities and borrowing capacity hampered any efforts by farmers to embrace adaptation strategies that required heavy investment such as irrigation buying of insurance, chemical fertilizers and aquaculture. This is in agreement with findings of Gbetibouo [22] and Shiferaw et al. [23] who found that under conditions of flawed credit, farmers will not adopt certain adaptation measures as adoption of new technologies required borrowed or owned capital.

Pertaining access to early warning weather information, the current study indicated that a unit increase in the number of sources of early warning weather information increased the probability of farmers adopting the adaptation strategies by a factor of 1.01 (coefficient $=0.005$; $p=0.68$; odds ratio=1.01). This implied that farmers with more sources of early warning weather information were more likely to adopt adaptation measures against climate variability and extremes. Access to climate information increased farmers' awareness and knowledge on the changing rainfall and temperature patterns as well as the possible climate variability response strategies making it easier for farmers to decide on viable adaptation strategies. A study by Gbeheh et al. [19] revealed that certain information sources can be more effective change agents than others and various information sources can influence the probability of adoption differently. Similarly, different sources of information become influential during different stages of adoption process. The present results are in line with findings of Mutunga et al. [14] who indicated that farmers with access to climate information were more likely to adopt climate variability adaptation measures as compared to farmers without access to climate information.

The number of times of accessing extension services negatively influenced adoption of the adaptation strategies (coefficient=-0.038; $\mathrm{p}=0.63$; odds ratio=0.96). This implied that, farmers with little or no access to extension services were more likely to adopt adaptation strategies than farmers with adequate access to the services. Personal observations and interactions with farmers suggested that farmers in the study area did not rely on extension service providers for information and implementation of adaptation strategies. Majority of farmers adopted planned or autonomous adaptation strategies once they perceived changes in precipitation trends and temperature regimes regardless of whether the county government provided extension services or not. The results contrast the findings of Gbetibouo [22] who found that farmers with access to extension services are likely to have information about climate and weather changes thus more knowledge on how to carry out adaptation strategies.

Both on-farm income and off-farm income did not have a significant influence adoption of adaptation strategies 
(coefficient=-0.00; $\mathrm{p}=0.44$; odds ratio=1.00; (coefficient $=-0.00$; $\mathrm{p}=0.77$; odds ratio $=1.00$ respectively). However, the odds ratios implied that, unit increase in on-farm and off-farm income increased the probability of farmers to adopt adaptation strategies by a factor of 1 . As expected, households with higher income had the ability to take up adaptation strategies that needed capital investment unlike households that had low income endowments. On-farm income was nonetheless less reliable in influencing adoption of adaptation strategies as it is affected by climate variability thus enhancing risk bearing capacity by farmers. Other studies have established that asset endowments and wealth have a significant influence on the ability of smallholder farmers to adopt certain technological practices [22,24]. The current results also agree with findings of Shiferaw et al. [23]; Ndung'u \& Bhardwaj [8] and Mutunga et al. [14] who found that households with higher income and greater assets are less risk averse than lower income households, and therefore in better position to adopt new farming technologies.

Pertaining agro-ecological zone background, the results revealed that the zones did not have a statistically significant influence on adoption of adaptation strategies (coefficient $=-0.060$; $\mathrm{p}=0.77$; odds ratio=1.06). However, the probability to adopt adaptation strategies increased by a factor of 1.06 in semi-humid areas (Kaveta and Kauwi sub-locations) compared to the arid areas (Kasaini and Yuku sub-locations). This could be attributed to proximity to town and County head offices thus more opportunities; improved socio-economic characteristics such as education level, monthly income, savings and trainings attended by family members in the semi-humid areas compared to the arid areas. The findings contradict studies by Mutunga et al. [14] who found that farmers in semi-arid areas had a higher probability of adopting adaptation measures to climate variability compared to those in semi-humid areas.

\section{Conclusion and Recommendation}

Farmers in the study areas had embraced multiple adaptation strategies to climate variability and extremes. The common adaptation strategies adopted by the farmers included use of organic manure, change of planting time, mixed crop and livestock system, use of pesticides, crop diversification, planting drought resistant crops, agro-forestry and use of improved crop variety at. The study results showed that gender, education level, farming experience and age significantly influenced farmers' adoption of adaptation strategies to climate variability and extremes in the study areas. However, the fact that most farmers had taken up multiple adaptation strategies to climate variability and extreme events does not mean that those adaptations were appropriate and effective in building resilience at the local contexts. While farmers in the study area had for a long time developed local adaptation strategies to cope with erratic environmental shocks, increased variability and extreme weather events had exceeded the present coping range and adaptive capacity particularly in the arid areas. Therefore, policies on adaptation that target farmers in vulnerable agro-ecological zones should be worked out by the County Government of Kitui through agricultural extension officers consultatively with farmers and other relevant stakeholders to ensure that feasible farmer adaptation strategies to climate variability and extremes are promoted and supported.

\section{Acknowledgement}

The authors are grateful to Climate Smart Agriculture Project, South Eastern Kenya University for sponsoring the study.

\section{References}

1. Nelson GC, Rosegrant MW, Koo J, Robertson R, Sulser T, et al. (2009) Climate change: Impact on agriculture and costs of adaptation. Food Policy Report \#19. IFPRI, Washington, DC.

2. Fussel HM (2007) Vulnerability: A generally applicable conceptual framework for climate change research. In: Global Environmental Change 17(2): 155-167.

3. Intergovernmental Panel on Climate Change (IPCC) (2001) Climate Change Impacts, Adaptation, and Vulnerability. Contribution of Working Group II to the 3rd Assessment Report Cambridge University Press, Cambridge.

4. Smit B, Olga P (2001) Assessment of adaptation practices, options, constraints and capacity, Adaptation to Climate Change in the Context of Sustainable Development and Equity.

5. Smit B, Wandel J (2006) Adaptation, adaptive capacity and vulnerability. Global Environmental Change 16(3): 282-292.

6. IPCC (2007) Impacts, adaptation and vulnerability - Contribution of Working Group II to the Fourth Assessment Report of the Intergovernmental Panel on Climate Change.

7. Ndambiri H, Ritho C, Mbogoh S, Nganga S, Muirur E, et al. (2012) Assessment of farmers' adaptation to effects of climate change in Kenya. J Econ Sust Dev 3(12).

8. Ndungu C, Bhardwaj S (2015) Assessment of People s Perceptions and Adaptation to Climate Change and Variability in Mid-Hills of Himachal Pradesh, India. International Journal of Current Microbiology and Applied Sciences 4(8): 47-60.

9. Mutunga EJ, Ndungu CK, Muendo, P (2017) Smallholder Farmers' Perceptions and Adaptations to Climate Change and Variability in Kitui County, Kenya. Journal of Earth Science and Climate Change 8: 389.

10. Adger WN, Agrawala MM, Mirza C, Conde K, O’Brien J, et al. (2007) Agricultural and Food Economics. Agriculture, Forestry and Other Land Use Emissions by Sources and Removals by Sinks.

11. Heltberg R, Siegel P, Jorgensen S (2008) Addressing Human Vulnerability to Climate Change: Towards a No Regrets Approach. Global Environmental Change 19(1): 89-99.

12. Burton I, Diringer E, Smith J (2006) Adaptation to Climate Change: International Policy Change. Global Climate Change. Pew Centre.

13. G.O.K (2009) National Census Report. By Kenya National Bureau of Statistics (KNBS) Nairobi Kenya.

14. Mutunga Evelyn J, Ndungu CK, Muendo P (2018) Factors Influencing Smallholder Farmers' Adaptation to Climate Variability in Kitui County, Kenya. International Journal of Environmental Sciences and Natural Resources 8(5): 555746. 
15. Fagariba CJ, Shaoxian S, Serge KG (2018) Climate Change Adaptation Strategies and Constraints in Northern Ghana: Evidence of Farmers in Sissala West District. Sustainability 10(5): 1484.

16. Ogallo EA (2014) Household Vulnerability and Adaptive Capacity to Impacts of Climate Change and Variability in Soroti Distict, Eastern Uganda. University of Nairobi, India.

17. Paavola J (2008) Livelihoods, Vulnerability and Adaptation to Climate Change in Morogoro, Tanzania. Environmental Science and Policy 11(7): 642-654

18. Kasirye I, Sarah SN, Ibrahim K (2010) Food security in Uganda: a dilemma to achieving the millennium development goal. Research Series 113614, Economic Policy Research Centre (EPRC).

19. Gbegeh BD, Akubuilo CJC (2012) Socioeconomic determinants of adoption of yam minisett by farmers in Rivers state, Nigeria. Wudpecker Journal of Agricultural Research 2(1): 033-038.

20. Adesina AA, Forson JB (1995) Farmers' perceptions and adoption of new agricultural technology: Evidence from analysis in Burkina Faso and Guinea, West Africa. Agricultural Economics 13(1): 1-9.
21. Deressa T, Hassan RM, Alemu T, Yesuf M, Ringler C (2008) Analyzing the determinants of farmers' choice of adaptation methods and perceptions of climate change in the Nile Basin of Ethiopia. IFPRI Discussion Paper 00798, September 2008.

22. Gbetibouo GA (2009) Understanding Farmers' Perceptions and Adaptation to Climate Change and Variability: The Case of the Limpopo Basin, South Africa. IFPRI Discussion Paper 00849 February 2009.

23. Shiferaw B, Holden S (1998) Resource degradation and adoption of land conservation technologies in the Ethiopian Highlands: A case study in Andit Tid, North Shewa. Slovic P, 2000: The Perception of Risk. Earthscan, London, UK 18(3): 233-247.

24. Nkonya E, Pender J, Kaizzi C, Kato E, Mugarura S, et al. (2008) Human Security, vulnerability, and sustainable adaptation. Background Paper commissioned for the Human Development Report: Fighting Climate Change.

\section{Your next submission with Juniper Publishers} will reach you the below assets

- Quality Editorial service

- Swift Peer Review

- Reprints availability

- E-prints Service

- Manuscript Podcast for convenient understanding

- Global attainment for your research

- Manuscript accessibility in different formats ( Pdf, E-pub, Full Text, Audio)

- Unceasing customer service

Track the below URL for one-step submission https://juniperpublishers.com/online-submission.php 